\title{
Investigation of Combining Ability and Gene Action for Seed Yield and its Component Traits in Pigeonpea [Cajanus cajan (L.) Millspaugh]
}

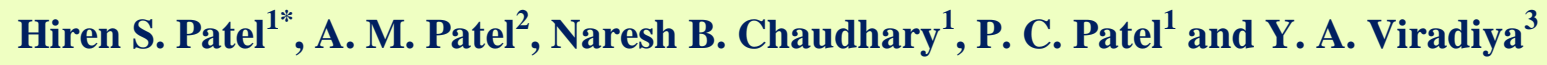 \\ ${ }^{1}$ Department of Genetics and Plant Breeding, S. D. Agricultural University, \\ Sardarkrushinagar, Gujarat, India \\ ${ }^{2}$ Seed Spices Research Station, S. D. Agricultural University, Jagudan, Gujarat, India \\ ${ }^{3}$ Department of Seed Technology, S. D. Agricultural University, Sardarkrushinagar,
} Gujarat, India

*Corresponding author

\section{A B S T R A C T}

To ascertain combining ability and genetic variance of thirteen quantitative characters by evaluating forty hybrids developed by line $\mathrm{x}$ tester mating design using ten females and four males in pigeonpea. Analysis of variance for combining ability revealed that variance

\section{Keywords}

Combining ability, gene action, GCA effects, SCA effects

\section{Article Info}

Accepted:

10 July 2020 Available Online: 10 August 2020 due to parents ( $\sigma^{2}$ gca) were found significant for majority of the traits under study except seed yield per plant and variance due to hybrids ( $\sigma^{2} \mathrm{sca}$ ) were found significant for all the traits under study, which indicates the presence of both additive and non additive gene action. A perusal of variance ratio ( $\sigma^{2}$ gca / $o^{2}$ sca) was less than unity suggested the preponderance of non additive genetic variance for all the characters except days to maturity. Based on estimates of general combining ability effects for various characters, the five parents were CMS GT 1603 A, CMS GT 1616 A, CMS GT 288 A, CMS GT 307 $A$ and GTR 97 were found good general combiners for seed yield and its contributing traits. Therefore these parents were noted as good source of favourable genes for increasing seed yield through various yield contributing characters. The estimates of SCA effects revealed that out of forty hybrids, twelve hybrids registered significant positive SCA effects for seed yield per plant. The best five hybrids on the basis of significant positive SCA effects for seed yield per plant were CMS GT 288 A x GTR 55, CMS GT 1616 A x GTR 55, CMS GT 1002 A x GTR 97, CMS GT 1402 A x GTR 18 and CMS GT 1602 A x GTR 23. On the basis of mean performance and specific combining ability for seed yield per plant and its component traits the hybrid CMS GT 288 A x GTR 55 was found most promising. Therefore it needs to be exploited in future breeding programme of pigeonpea.

\section{Introduction}

Pigeonpea (Cajanus cajan (L.) Mills paugh) is a short lived perennial shrub belonging to the economically most important tribe Phaseoleae, subtribe Cajaninae and family fabaceae with chromosome number $2 \mathrm{n}=2 \mathrm{x}=$ 22. In India it is one of the very important 
grain legume and occupies second position in area and production next to chickpea. The East Indies is the primary center of origin for pigeonpea (Linnaeus, 1937). Vavilov (1939) has also reported that India is the native of pigeonpea. The Indian sub-continent, Eastern Africa and Central America, are the world's three main pigeonpea producing regions. The pigeonpea flowers are bisexual, zygomorphic and predominantly yellow in colour.

The largest, auricled and erect petal forms the standard; two lateral, obliquely obovate and incurved clawed petals are known as wings; the two innermost obtuse, incurved and boat shaped petals are fused to form the keel to protect the stigma and style. Pigeonpea is an often cross-pollinated crop with 25-70 \% natural out-crossing reported from different locations (Saxena et al.,, 1990). This considerable amount of natural out crossing has been used efficiently in hybrid breeding technology.

Saxena (2007) reported that CGMS based pigeonpea hybrids gave $50-100 \%$ yield advantage over the popular variety. Information on combining ability provide guidelines to plant breeders in selecting the elite parents and desirable cross combinations to be used in formulation of efficient breeding programme and at the same time reveals the nature and magnitude of gene action involved in the inheritance of various traits. It also provides the vital and necessary information on the nature of gene action governing the expression of the character (Salimath et al., 1985). The ability of parent to combine will depend on complex interaction among genes, which cannot be predicted from yield adaptability of parents (Kumar et al.,, 1999). The success of breeding procedure is determined by the useful gene combinations organized in the form of good combining lines and isolation of valuable germplasm.

\section{Materials and Methods}

The experimental material comprised of ten CMS lines (CMS GT 1001 A, CMS GT 1002 A, CMS GT 1003 A, CMS GT 1402 A, CMS GT 301 A, CMS GT 307 A, CMS GT 1616 A, CMS GT 288 A, CMS GT 1603 A and CMS GT 1602 A) and four fertility restoration (R) lines (GTR 97, GTR 55, GTR 23 and GTR 18) following line $x$ tester mating design as suggested by Kempthorne (1957) during kharif 2017-18 at Pulses Research Station, Sardarkrushinagar Dantiwada Agricultural University, Sardarkrushinagar, Gujarat, India.

The complete set of fifty five genotypes comprising ten male sterile (A) lines, four male fertile $(\mathrm{R})$ lines, resultant forty hybrids and one standard check variety (GT 103) were evaluated in a Randomized Block Design (RBD) with three replications at the Department of Seed Technology, Sardarkrushinagar Dantiwada Agricultural University, Sardarkrushinagar, Gujarat, India during kharif 2018-19. Each male sterile and fertile line was accommodated in 3 meter long row with inter and intra row spacing of $60 \mathrm{~cm}$ $\mathrm{x} 45 \mathrm{~cm}$. Recommended agronomic practices and plant protection measures were followed to raise a healthy crop.

The observations were recorded based on five randomly selected competitive plants for various thirteen characters i.e., plant height (cm), number of branches per plant, number of pods per plant, pod length $(\mathrm{cm})$, number of seeds per pod, 100 seed weight $(\mathrm{g})$, seed yield per plant $(\mathrm{g})$, biological yield per plant $(\mathrm{g})$, harvest index (\%), total Protein content (\%) and leaf area per plant $\left(\mathrm{cm}^{2}\right)$ in each replication for each genotype and the average value per plant was computed except for the phonological characters viz., days to flowering and days to maturity, which were recorded on plot basis. The general combining 
ability variances (ó ${ }^{2}$ gca) and specific combining ability variances (ó ${ }^{2}$ sca) were worked out as per the method given by Kempthorne (1957).

\section{Results and Discussion}

The concept of general and specific combining ability as a measure of gene action was proposed by Sprague and Tatum (1942). The total genetic variance is partitioned into the variance due to $g c a$ and $s c a$.

This helps in ascertaining the relative proportion of additive and non-additive variances in the inheritance of individual traits that is the decisive basis for choosing the appropriate breeding methods for effective exploitation of the available genetic variation.

The analysis of variance for combining ability was done for thirteen characters were presented in Table 1. Analysis of variance for combining ability revealed that mean squares due to females (lines) were highly significant for most of the characters except number of seeds per pod, seed yield per plant and total protein content. Whereas for mean squares due to males (testers), it was highly significant for days to flowering only.

The mean squares due to females $\mathrm{x}$ males interaction were highly significant for all the characters, suggesting that line $\mathrm{x}$ tester interaction variance contributed largely for total genetic variance and both lines and testers interacted differently in cross combinations.

Variance due to gca was found significant for majority of the traits under study except seed yield per plant whereas variance due to sca was found significant for all the traits which indicate the presence of both additive and non additive gene action.
A perusal of variance ratio $\left(o^{2}\right.$ gca / ó ${ }^{2}$ sca) less than unity for most of the characters under study except days to maturity suggested the preponderance of non-additive gene action. Thus, it emphasizes the use of heterosis breeding approach to exploit available vigour in pigeonpea.

\section{General combining ability}

An average performance of a line in a series of cross combinations termed as general combining ability and it can be recognized as a measure of additive type of gene action. The parents having significant GCA effect in desired direction, non-significant GCA effect in desired direction and significant GCA effect in undesired direction were classified as good, average and poor general combiner, respectively; accordingly crosses were also classified as good, average and poor specific combiner.

The estimates of GCA effect revealed that the lines CMS GT 1603 A, CMS GT 1616 A and CMS GT 288 A were found good general combiner for seed yield per plant and its contributing traits like number of branches per plant, number of pods per plants and pod length. Whereas Line CMS GT 307 A was registered good general combiner for seed yield per plant and its component traits like number of branches per plant, number of pods per plants, biological yield per plant, total protein content and leaf area per plant. Among the tester, GTR 97 was proved to be a good general combiner for seed yield per plant and its contributing traits like biological yield per plant and leaf area per plant.

For days to flowering and days to maturity, the lines CMS GT 288 A, CMS GT 301 A, CMS GT 307 A and tester GTR 18 were found good general combiner. Based on present study we can conclude that the lines as well as tester which were identified as 
good general combiner for seed yield per plant and its component traits can be directly exploited in the heterosis breeding programme.

Estimates of GCA effects and summarized information of GCA effects of parents for different characters in pigeonpea were presented in Table 2 and Table 3, respectively.

\section{Specific combining ability}

Whereas, specific combining ability defined as the deviation from the expected performance of specific hybrid combination on the basis of average performance of parents involved in the crosses and it can be regarded as a measure of non additive gene action resulted from both intra allelic and inter allelic gene action.

Table.1 Analysis of variance for combining ability for different characters in pigeon pea

\begin{tabular}{|c|c|c|c|c|c|c|c|c|}
\hline $\begin{array}{c}\text { Sources of } \\
\text { variation }\end{array}$ & d.f & $\begin{array}{c}\text { Days to } \\
\text { flowering }\end{array}$ & $\begin{array}{l}\text { Days to } \\
\text { maturity }\end{array}$ & Plant height & $\begin{array}{c}\text { No. of } \\
\text { branches } \\
\text { per plant }\end{array}$ & $\begin{array}{l}\text { No. of } \\
\text { pods per } \\
\text { plant }\end{array}$ & $\begin{array}{c}\text { Pod } \\
\text { length }\end{array}$ & $\begin{array}{l}\text { No. of seeds } \\
\text { per pod }\end{array}$ \\
\hline Replications & 2 & 4.00 & 26.65 & 499.86 & 1.06 & 259.00 & 0.03 & 0.14 \\
\hline Females (Lines) & 9 & $267.96 * *$ & $547.18 * *$ & $3842.53 * *$ & $119.90 * *$ & $4459.41 * *$ & $1.18 * *$ & 0.13 \\
\hline Males (Testers) & 3 & $221.63 *$ & 184.33 & 210.64 & 16.90 & 549.54 & 0.30 & 0.15 \\
\hline $\begin{array}{c}\text { Females x } \\
\text { Males }\end{array}$ & 27 & $66.76 * *$ & $64.09 * *$ & $424.73 * *$ & $24.77 * *$ & $842.63 * *$ & $0.262 * *$ & $0.085^{*}$ \\
\hline Error & 78 & 15.82 & 18.30 & 131.70 & 2.50 & 67.75 & 0.05 & 0.05 \\
\hline \multicolumn{9}{|c|}{ Components of variance } \\
\hline$\sigma^{2}$ Females & - & $21.09 * *$ & $44.17 * *$ & $309.13 * *$ & $9.79 * *$ & $366.23 * *$ & $0.093 * *$ & 0.00 \\
\hline$\sigma^{2}$ Males & - & $6.89 *$ & 5.57 & 2.59 & 0.48 & 16.16 & 0.00 & 0.00 \\
\hline$\sigma_{\text {gca }}^{2}$ & - & $10.94 * *$ & $16.60 * *$ & $90.17 * *$ & $3.14 * *$ & $116.18 * *$ & $0.032 * *$ & $0.0045^{* *}$ \\
\hline$\sigma_{\text {sca }}^{2}$ & - & $17.29 * *$ & $15.68 * *$ & $97.26 * *$ & $7.47 * *$ & $259.35 * *$ & $0.068 * *$ & $0.0115^{*}$ \\
\hline$\sigma_{\mathrm{gca}}^{2} / \sigma_{\mathrm{sca}}^{2}$ & - & 0.63 & 1.05 & 0.92 & 0.42 & 0.44 & 0.47 & 0.39 \\
\hline
\end{tabular}

\begin{tabular}{|c|c|c|c|c|c|c|c|}
\hline $\begin{array}{c}\text { Sources of } \\
\text { variation }\end{array}$ & d.f & $\begin{array}{c}100 \\
\text { seed } \\
\text { weight }\end{array}$ & $\begin{array}{c}\text { Seed } \\
\text { yield per } \\
\text { plant }\end{array}$ & $\begin{array}{l}\text { Biological } \\
\text { yield per } \\
\text { plant }\end{array}$ & $\begin{array}{l}\text { Harvest } \\
\text { index }\end{array}$ & $\begin{array}{c}\text { Total protein } \\
\text { content }\end{array}$ & $\begin{array}{c}\text { Leaf area per } \\
\text { plant }\end{array}$ \\
\hline Replications & 2 & 0.29 & 141.72 & 246.89 & 11.97 & 0.35 & 185800.89 \\
\hline Females (Lines) & 9 & $2.53 *$ & 1360.27 & $28319.55^{* *}$ & $529.13 *$ & 5.88 & $173992288.49 *$ \\
\hline Males (Testers) & 3 & 0.27 & 213.93 & 3620.76 & 96.29 & 2.31 & 168262633.01 \\
\hline Females x Males & 27 & $0.820 * *$ & $834.66 * *$ & $5209.24 * *$ & $185.83 * *$ & $2.88 * *$ & $70138401.65 * *$ \\
\hline Error & 78 & 0.26 & 35.94 & 258.29 & 20.21 & 0.12 & 1028713.65 \\
\hline \multicolumn{8}{|c|}{ Components of variance } \\
\hline$\sigma^{2}$ Females & - & $0.190 *$ & 110.40 & $2341.71 * *$ & $42.38 *$ & 0.48 & $14413428.23^{*}$ \\
\hline$\sigma^{2}$ Males & - & 0.00 & 5.95 & 113.39 & 2.52 & 0.07 & 5574382.77 \\
\hline$\sigma_{\text {gca }}^{2}$ & - & $0.055^{* *}$ & 35.79 & $750.05^{* *}$ & $13.91 * *$ & $0.189 *$ & $8099824.33 * *$ \\
\hline$\sigma_{\text {sca }}^{2}$ & - & $0.191 * *$ & $266.43 * *$ & $1663.44 * *$ & $55.11 * *$ & $0.922 * *$ & $23035750.67 * *$ \\
\hline$\sigma_{\text {gca }}^{2} / \sigma_{\text {sca }}^{2}$ & - & 0.26 & 0.13 & 0.45 & 0.25 & 0.19 & 0.35 \\
\hline
\end{tabular}

*** Significant at 5 percent and 1 percent levels of significance, respectively 
Table.2 Estimates of general combining ability (GCA) effects of the parents for various characters in pigeon pea

\begin{tabular}{|c|c|c|c|c|c|c|c|c|c|c|c|c|c|}
\hline Parents & $\begin{array}{c}\text { Days to } \\
\text { flowering }\end{array}$ & $\begin{array}{l}\text { Days to } \\
\text { maturity }\end{array}$ & $\begin{array}{l}\text { Plant } \\
\text { height }\end{array}$ & $\begin{array}{c}\text { No. of } \\
\text { branch } \\
\text { es per } \\
\text { plant }\end{array}$ & $\begin{array}{c}\text { No. of } \\
\text { pods per } \\
\text { plant }\end{array}$ & $\begin{array}{c}\text { Pod } \\
\text { length }\end{array}$ & $\begin{array}{c}\text { No. of } \\
\text { seeds } \\
\text { per } \\
\text { pod }\end{array}$ & $\begin{array}{c}100 \\
\text { seed } \\
\text { Weight }\end{array}$ & $\begin{array}{c}\text { Seed } \\
\text { yield per } \\
\text { Plant }\end{array}$ & $\begin{array}{c}\text { Biological } \\
\text { yield per } \\
\text { plant }\end{array}$ & $\begin{array}{c}\text { Harvest } \\
\text { index }\end{array}$ & $\begin{array}{c}\text { Total } \\
\text { protein } \\
\text { content }\end{array}$ & $\begin{array}{l}\text { Leaf area } \\
\text { per plant }\end{array}$ \\
\hline \multicolumn{14}{|l|}{ Lines } \\
\hline CMS GT 1001A & $-2.87 *$ & -1.73 & -2.61 & $-3.07 * *$ & $-13.87 * *$ & $-0.24 * *$ & $-0.14^{*}$ & $-0.31^{*}$ & $-7.67 * *$ & $-31.16^{* *}$ & -1.37 & $1.28 * *$ & $2265.04 * *$ \\
\hline CMS GT 1002A & $-2.45^{*}$ & $3.85 * *$ & $-18.43 * *$ & $-3.10 * *$ & $-21.51 * *$ & $-0.21 * *$ & -0.02 & -0.09 & $-13.68 * *$ & $-107.81 * *$ & $16.04 * *$ & $-1.24 * *$ & $-2713.16 * *$ \\
\hline CMS GT 1003A & 1.54 & 0.68 & $-34.29 * *$ & $-3.33 * *$ & $-29.93 * *$ & 0.04 & -0.09 & $-0.36^{*}$ & $-7.77 * *$ & $-11.10 *$ & $-2.70^{*}$ & -0.17 & $-1241.34 * *$ \\
\hline CMS GT 1402A & $10.70 * *$ & $9.35 * *$ & $21.55 * *$ & $-1.15^{*}$ & $7.46 * *$ & -0.07 & -0.02 & $-0.34 *$ & $-4.74 * *$ & $48.71 * *$ & $-8.43 * *$ & 0.14 & $4263.78 * *$ \\
\hline CMS GT 301A & $-3.12 * *$ & $-6.23 * *$ & -5.56 & $-1.45 * *$ & $-10.97 * *$ & $-0.43 * *$ & $-0.14^{*}$ & $-0.58 * *$ & $-6.57 * *$ & $-26.63 * *$ & 0.89 & $0.49 * *$ & $6918.49 * *$ \\
\hline CMS GT 307A & $-2.95 * *$ & $-7.73 * *$ & -4.58 & $2.22 * *$ & $13.84 * *$ & $-0.35^{* *}$ & 0.02 & -0.04 & $6.02 * *$ & $47.08 * *$ & $-4.39 * *$ & $0.71 * *$ & $1296.56^{* *}$ \\
\hline CMS GT 1616A & -2.20 & $-6.15 * *$ & $16.45^{* *}$ & $3.91 * *$ & $21.19 * *$ & $0.23 * *$ & 0.04 & 0.23 & $8.36^{* *}$ & $18.95 * *$ & -1.33 & -0.15 & $629.20 *$ \\
\hline CMS GT 288A & $-4.70 * *$ & $-6.98 * *$ & 5.09 & $1.89 * *$ & $12.65^{* *}$ & $0.30 * *$ & 0.09 & $0.42 * *$ & $8.27 * *$ & 1.89 & $4.59 * *$ & $-0.31 * *$ & $-5386.04 * *$ \\
\hline CMS GT 1603A & $4.70 * *$ & $9.43 * *$ & $23.34 * *$ & $5.51 * *$ & $27.77 * *$ & $0.49 * *$ & $0.19 * *$ & $0.97 * *$ & $21.44 * *$ & $53.01 * *$ & 0.67 & $-0.42 * *$ & $-2263.21 * *$ \\
\hline CMS GT 1602A & 1.37 & $5.51 * *$ & -0.96 & $-1.42 * *$ & $-6.63 * *$ & $0.24 * *$ & 0.06 & 0.11 & $-3.65^{*}$ & 7.05 & $-3.96 * *$ & $-0.32 * *$ & $-3769.31 * *$ \\
\hline S. Em. \pm & 1.11 & 1.19 & 3.32 & 0.44 & 2.31 & 0.06 & 0.06 & 0.14 & 1.71 & 4.27 & 1.30 & 0.09 & 293.13 \\
\hline \multicolumn{14}{|l|}{ Testers } \\
\hline GTR 97 & 0.04 & 1.26 & -2.19 & 0.38 & -2.15 & $-0.11 *$ & 0.01 & -0.00 & $3.20 * *$ & $16.12 * *$ & -1.53 & -0.07 & $2331.35^{* *}$ \\
\hline GTR 55 & $2.70 * *$ & $2.80 * *$ & -0.50 & 0.26 & -2.67 & -0.01 & $-0.08^{*}$ & -0.03 & -0.14 & -5.24 & 0.33 & $-0.34 * *$ & $1528.73^{* *}$ \\
\hline GTR 23 & 0.97 & -1.43 & 3.83 & 0.47 & $6.38 * *$ & $0.12 * *$ & $0.09 *$ & 0.13 & 0.25 & $-8.21 * *$ & $2.39 * *$ & 0.09 & $-1034.53 * *$ \\
\hline GTR 18 & $-3.72 * *$ & $-2.63 * *$ & -1.13 & $-1.11 * *$ & -1.54 & -0.00 & -0.02 & -0.09 & $-3.31 * *$ & -2.66 & -1.19 & $0.31 * *$ & $-2825.55 * *$ \\
\hline S. Em. \pm & 0.70 & 0.75 & 2.10 & 0.28 & 1.46 & 0.04 & 0.04 & 0.09 & 1.08 & 2.70 & 0.82 & 0.06 & 185.39 \\
\hline
\end{tabular}

*,** Significant at 5 percent and 1 percent levels of significance, respectively 
Table.3 Summarized information of general combining ability (GCA) effects of the parents for different characters in pigeonpea

\begin{tabular}{|c|c|c|c|c|c|c|c|c|c|c|c|c|c|}
\hline Parents & $\begin{array}{c}\text { Days to } \\
\text { flowering }\end{array}$ & $\begin{array}{l}\text { Days to } \\
\text { maturity }\end{array}$ & $\begin{array}{l}\text { Plant } \\
\text { height }\end{array}$ & $\begin{array}{l}\text { No. of } \\
\text { branches } \\
\text { per plant }\end{array}$ & $\begin{array}{c}\text { No. of } \\
\text { pods per } \\
\text { plant }\end{array}$ & $\begin{array}{l}\text { Pod } \\
\text { length }\end{array}$ & $\begin{array}{l}\text { No. of } \\
\text { seeds per } \\
\text { pod }\end{array}$ & $\begin{array}{c}100 \\
\text { seed } \\
\text { Weight }\end{array}$ & $\begin{array}{c}\text { Seed } \\
\text { yield per } \\
\text { Plant }\end{array}$ & $\begin{array}{l}\text { Biologica } \\
\text { l yield } \\
\text { per plant }\end{array}$ & $\begin{array}{l}\text { Harvest } \\
\text { index }\end{array}$ & $\begin{array}{l}\text { Total } \\
\text { protein } \\
\text { content }\end{array}$ & $\begin{array}{l}\text { Leaf area } \\
\text { per plant }\end{array}$ \\
\hline \multicolumn{14}{|l|}{ Lines } \\
\hline CMS GT 1001A & G & A & A & $\mathrm{P}$ & $\mathrm{P}$ & $\mathrm{P}$ & $\mathrm{P}$ & $\mathrm{P}$ & $\mathrm{P}$ & $\mathrm{P}$ & A & G & G \\
\hline CMS GT 1002A & G & $\mathrm{P}$ & G & $\mathrm{P}$ & $\mathrm{P}$ & $\mathrm{P}$ & A & A & $\mathrm{P}$ & $\mathrm{P}$ & G & $\mathrm{P}$ & $\mathrm{P}$ \\
\hline CMS GT 1003A & A & A & G & $\mathrm{P}$ & $\mathrm{P}$ & A & A & $\mathrm{P}$ & $\mathrm{P}$ & $\mathrm{P}$ & $\mathrm{P}$ & A & $\mathrm{P}$ \\
\hline CMS GT 1402A & $P$ & $\mathrm{P}$ & $\mathrm{P}$ & $\mathrm{P}$ & G & A & A & $\mathrm{P}$ & $\mathrm{P}$ & G & $\mathrm{P}$ & A & G \\
\hline CMS GT 301A & G & G & A & $\mathrm{P}$ & $\mathrm{P}$ & $\mathrm{P}$ & $\mathrm{P}$ & $\mathrm{P}$ & $\mathrm{P}$ & $\mathrm{P}$ & A & G & G \\
\hline CMS GT 307A & G & G & A & G & G & $\mathrm{P}$ & A & A & G & G & $\mathrm{P}$ & G & G \\
\hline CMS GT 1616A & A & G & $\mathrm{P}$ & G & G & G & A & A & G & G & A & A & G \\
\hline CMS GT 288A & G & G & A & G & G & G & A & G & G & A & G & $\mathrm{P}$ & $\mathrm{P}$ \\
\hline CMS GT 1603A & $\mathrm{P}$ & $\mathrm{P}$ & $\mathrm{P}$ & G & G & G & G & G & G & G & A & $\mathrm{P}$ & $\mathrm{P}$ \\
\hline CMS GT 1602A & A & $\mathrm{P}$ & A & $\mathrm{P}$ & $P$ & G & A & A & $\mathrm{P}$ & A & $\mathrm{P}$ & $\mathrm{P}$ & $\mathrm{P}$ \\
\hline \multicolumn{14}{|l|}{ Testers } \\
\hline GTR 97 & A & A & A & A & A & $\mathrm{P}$ & A & A & G & G & A & A & G \\
\hline GTR 55 & $\mathrm{P}$ & $\mathrm{P}$ & A & A & A & A & $\mathrm{P}$ & A & A & A & A & $\mathrm{P}$ & G \\
\hline GTR 23 & A & A & A & A & G & G & G & A & A & $\mathrm{P}$ & G & A & $\mathrm{P}$ \\
\hline GTR 18 & G & G & A & $\mathrm{P}$ & A & A & A & A & $\mathrm{P}$ & A & A & G & $\mathrm{P}$ \\
\hline $\begin{array}{l}\mathrm{G} \\
\mathrm{P} \\
\mathrm{A}\end{array}$ & $\begin{array}{l}\text { Go } \\
\text { Po } \\
\text { Av }\end{array}$ & $\begin{array}{l}\text { seneral co } \\
\text { eneral cor } \\
\text { ge general }\end{array}$ & $\begin{array}{l}\text { iner } \\
\text { ner } \\
\text { mbiner }\end{array}$ & & & & & & & & & & \\
\hline
\end{tabular}


Table.4 Five promising hybrids based on SCA effects of seed yield per plant and its component characters in pigeon pea

\begin{tabular}{|c|c|c|c|c|}
\hline Sr. No. & Hybrids & $\begin{array}{c}\text { Mean performance } \\
\text { of seed yield per } \\
\text { plant } \mathbf{( g m})\end{array}$ & $\begin{array}{c}\text { SCA } \\
\text { effects }\end{array}$ & $\begin{array}{c}\text { Component traits showing } \\
\text { SCA effects in desired } \\
\text { direction }\end{array}$ \\
\hline $\mathbf{1}$ & CMS GT 288 A x GTR 55 & 86.70 & $22.97 * *$ & NBP, NPP, 100 SW, BYP \\
\hline $\mathbf{2}$ & CMS GT 1616 A x GTR 55 & 86.07 & $22.24 * *$ & NBP, NPP, 100 SW, BYP, \\
LAP
\end{tabular}

The estimates of SCA effects revealed that none of the hybrid was consistently significantly superior for all the traits. Out of forty hybrids evaluated, twelve hybrids registered significant positive SCA effects for seed yield per plant. The best five hybrids on the basis of significant positive SCA effects for seed yield per plant were CMS GT 288 A x GTR 55, CMS GT 1616 A x GTR 55, CMS GT 1002 A x GTR 97, CMS GT 1402 A x GTR 18 and CMS GT 1602 A x GTR 23. Among these hybrids CMS GT 288 A x GTR 55, CMS GT 1616 A x GTR 55 and CMS GT 1402 A x GTR 18 were also reported significant SCA effect in desired direction for seed yield contributing traits like number of branches per plant, number of pods per plant and 100 seed weight. Whereas hybrid CMS GT 1002 A x GTR 97 was registered significant SCA effect for seed yield contributing traits like number of pods per plant, pod length, number of seeds per pod, biological yield per plant, harvest index and total protein content. Likewise hybrid CMS GT 1602 A x GTR 23 was reported significant SCA effect for seed yield contributing traits like number of branches per plant, number of pods per plant, pod length, harvest index and leaf area per plant. The five promising hybrids with high SCA effects involved the parents with good $\mathrm{x}$ average, good $\mathrm{x}$ average, poor $\mathrm{x}$ good, poor $\mathrm{x}$ poor and poor $\mathrm{x}$ average, respectively for seed yield per plant and its component characters under investigation were presented in Table 4. This indicates the significance of both additive and non additive gene action in governing the traits. Whereas three hybrids CMS GT 1603 A x GTR 18, CMS GT 1002 A x GTR 23 and CMS GT 301 A x GTR 55 were registered significant negative SCA effects for days to flowering and days to maturity.

Non additive gene action was recorded for seed yield per plant, which showed similarity with results of Reddy et al., (2004), Banu et al., (2006), Phad et al., (2006), Baskaran and Muthiah (2007), Gupta et al., (2011), Patel and Tikka (2014), Mhasal et al., (2015) and Soni et al., (2016). For number of branches per plant non additive gene action was recorded, for this similar findings reported by Lohitaswa and Dharmaraj (2003), Reddy et 
al., (2004), Banu et al., (2006) and Soni et al., (2016) indicates higher SCA effects. Non additive gene action for number of seeds per pod were also reported by Srinivas et al., (2000), Kumar et al., (2001), Chauhan et al., (2003), Lohitaswa and Dharmaraj (2003), Reddy et al., (2004), Banu et al., (2006), Phad et al., (2006), Baskaran and Muthiaha (2007) and Soni et al., (2016).

A perusal of variance ratio (ón ${ }^{2}$ gca / ó ${ }^{2}$ sca) being more than unity was found for days to maturity which suggested greater role of additive gene action in the inheritance of this trait. Thus it can be improved further as a source of favourable genes for earliness, seed yield and its contributing characters through selection of desired transgressive segregant's from segregating generations. The above results were in accordance with the findings of Khorgade et al., (2000), Kumar et al., (2001), Acharya et al., (2009), Mhasal et al., (2015) and Soni et al., (2017) for days to maturity.

In conclusion the present investigation, overall results revealed that the line CMS GT 288 A was proved to be good general combiner for seed yield per plant and its contributing traits and also for days to flowering and days to maturity. Based on mean performance and significant SCA effect for seed yield per plant and its component traits the hybrid CMS GT 288 A x GTR 55 was found most promising. Therefore it needs to be exploited in future breeding programme of pigeonpea.

\section{References}

Acharya, S, J. B.; Tank, C. J. and Yadav, A. S. (2009). Heterosis and combining ability studies in Indo-African crosses of pigeon pea. Journal of Food Legumes. 22(2): 91-95.

Banu, M. R.; Muthaiah, A. R. and Ashok, S.
(2006). Combining ability studies in pigeon pea. Crop Research. 31(3): 396398.

Baskaran, K. and Muthiah, A. R. (2007). Association between yield and yield attributes in pigeon pea. Legume Research. 30(1): 64-66.

Chauhan, R. M. and Tikka, S. B. S. (2003). Combining ability analysis studies in pigeonpea. Gujarat Agricultural Universities Research Journal. 28(1): 5-8.

Gupta, D. K.; Acharya, S. and Patel, J. B. (2011). Combining ability and heterosis studies in pigeonpea using $\mathrm{A}_{2}$ cytoplasm from Cajanus scarabaeoides as source of male sterility. Journal of Food Legumes. 24(1): 58-64.

Kempthone, O. (1957). An introduction to Genetical Statistics. John Wiley and Sons, Inc. New York. Champan and Hall, Ltd.

Khorgade, P. W.; Wankhade, R. R. and Wanjari, K. B. (2000). Combining ability analysis in pigeon pea using male sterile lines. Indian Journal of Agricultural Research. 34(2): 112-116.

Kumar, A.; Srivastava, D. P.; Singh, I. P. and Dixit, G. P. (2001). Combining ability analysis of male sterile lines and hybrids in pigeon pea. Legume Research. 24(3): 178-181.

Kumar, S.; Rheenen, H. A. and Sing, O. (1999). Genetic analysis of different components of crop duration in chickpea. Indian Journal of genetics. 55: 184-200.

Linnaeus, C. (1937). Hortusdiffortianns. Amst-elaedami. In: Proceeding of International Workshop on Pigeon pea, December, 1980, ICRISAT, Patancheru, India. 2: 354.

Lohithaswa, H. C and Dharmaraj, P. S. (2003). Implications of heterosis, combining ability and per se performance in pigeon pea. Karnataka 
Journal of Agricultural Sciences. 16(3): $403-407$.

Mhasal, G. S.; Marawar, M. W.; Solanke, A. C. and Tayade, S. D. (2015). Heterosis and Combining ability studies in medium duration pigeonpea $\mathrm{F}_{1}$ hybrids. Journal of Agricultural Sciences. 53(1): 11-22.

Patel, P. T. and Tikka, S. B. S. $\left(2014^{\mathrm{a}}\right)$. Gene action and Stability parameters for yield and yield components, maturity duration and protein content of CGMS lines, pollen fertility restorers and their hybrids in pigeonpea [Cajanus cajan (L.) Millsp.]. Euphytica. 199: 349-362.

Phad, D. S.; Madrap, I. A. and Dalvi, V. A. (2006). Combining ability analysis in pigeon pea under different environments. Indian Journal of Pulses Research. 19(2): 176-178.

Reddy, S. M.; Singh, S. P.; Mehra, R. B. and Govil, J. N. (2004). Combining ability and heterosis in early maturing pigeonpea [Cajanus cajan (L.) Millsp.] hybrids. Indian Journal of Genetics. 64(3): 212-216.

Salimath, P. M.; Bahl, P. N. and Mehta, R. B. (1985). Genetic diversity in chickpea (Cicer arietinum ). Pflanzenzuchtg. 92: 52-60.

Saxena, K. B.; Singh, L. and Gupta, M. D. (1990). Variation for natural outcrossing in pigeonpea. Euphytica. 46: 143-148.
Saxena, K.B. (2007). Breeding hybrids for enhancing productivity in pigeonpea. Paper presented at 7 th International conference on sustainable agriculture for food, bio-energy and livelihood security.

Soni, N. and Patel, P. T. (2016). Gene action and combining ability of cytoplasmic genic male sterility system based hybrids in pigeonpea [Cajanus Cajan (L.) Millsp.]. International Journal of Horticulture. 6(24):1-7.

Soni, N.; Patel, P. T.; Suresh, K. and Tak, V. (2017). Heterosis for Yield and its Component Traits in $\mathrm{F}_{1}$ Hybrids Involving CMS Lines and Restorer Lines in Pigeon pea [Cajanus cajan (L.) Millsp.]. Research Journal of Agricultural Sciences. 8(2): 286-293.

Sprague, G. F. and Tatum, L. A. (1942). General vs. specific combining ability in single crosses of corn. Journal of American Society of Agronomy. 34: 923-932.

Srinivas, T.; Jain, K. C. and Reddy, M. S. S. (2000). Combining ability studies of sterility mosaic resistant pigeonpea [Cajanus cajan (L.) Millsp.]. Crop Research. 15(1): 99-103.

Vavilov, N. I. (1939). The New Systematic of Cultivated Plants. In: Hynbey Journal (Ed.). The New Systematic, London, U.K. Oxford Univ. Press. pp. 249-566.

\section{How to cite this article:}

Hiren S. Patel, A. M. Patel, Naresh B. Chaudhary, P. C. Patel and Viradiya, Y. A. 2020. Investigation of Combining Ability and Gene Action for Seed Yield and its Component Traits in Pigeonpea [Cajanus cajan (L.) Mills paugh]. Int.J.Curr.Microbiol.App.Sci. 9(08): 10951103. doi: https://doi.org/10.20546/ijcmas.2020.908.120 